\title{
Middle School Students' Attitudes Towards Technology In Relation To Demographic And Affective Domain
}

\author{
Nurettin SAHIN \\ Muğla Sttkı Koçman Üniversitesi Ĕgitim Fakültesi, Menteşe, Muğla \\ Emel EKLI \\ M.E.B. Güney Ortaokulu, Yeşilova-Burdur \\ Sabahattin DENIZ \\ Muğla Sitkı Koçman Üniversitesi Ĕ̆itim Fakültesi, Menteşe, Muğla
}

\begin{abstract}
The study investigates middle school students' attitudes towards technology and key variables influencing these attitudes. For this purpose, the present study was carried out among 1,396 students in the $6^{\text {th }} 7^{\text {th }}$ and $8^{\text {th }}$ grades (age range 12-15) attending 23 middle schools, of which 708 $(50.7 \%)$ were female and $688(49.3 \%)$ were male. A validated national version of Pupils' Attitude towards Technology (TR-PATT) was used to determine their attitudes towards technology. A majority of the students had positive attitudes towards technology. There were significant differences between male and female students' attitudes. Moreover, it was found that attending schools in urban areas, having prior technology training, and having parents with technology-related jobs had positive impacts on attitudes towards technology. However, as grade level increased, trust in technology decreased. They described technology in terms of household appliances, computers, and the internet and stated that it made life easier. A large majority of the students stated that technology was useful for the country; that, because of technology, everything works well; and that technology is the future.
\end{abstract}

Keywords: Technology education; attitude; motivation; middle school

\section{Ortaokul Öğrencilerinin Demografik ve Duyuşsal Alana Bağlı Olarak Teknolojiye Karşı Tutumları}

\begin{abstract}
$\ddot{O}_{\text {zet }}$
Araştırmada ortaokul öğrencilerinin, teknolojiye yönelik tutumları ve tutumları üzerinde etkili temel değişkenler incelenmiştir. Bu amaçla, yapılan çalışma 708'i kuz (\%50.7), 688'i erkek (\%49.3) ögrenci olmak üzere toplam 1396 öğrenciye uygulanmıştır. Çalışmada orjinal formu Türkçeye daha önce uyarlanan teknolojiye yönelik tutum ölçeği (TR-PATT) kullanılmıştır. Öğrencilerin büyük çoğunluğu teknolojiye yönelik olumlu tutumlara sahiptirler. Cinsiyet değişkeni açısindan, erkek ve bayan ögrencilerin tutumları arasında anlaml farklllıklar elde edilmiștir. Merkez ya da kirsal okullarda okuma, teknoloji eğitimi olma, anne-babanın teknoloji ile ilişskili bir işe sahip olması gibi değişkenlerin teknolojiye yönelik tutumlar üzerinde olumlu etkilere sahip olduğu sonucuna ulaşılmıştır. Ancak, slnıf seviyesi arttıkça teknolojiye duyulan güvenin azaldlğı sonucuna ulaşılmış̧tr. Öğrenciler teknolojiyi tüketici elektroniği ürünleri, bilgisayar ve internet olarak tanımlanmış ve yaşamı kolaylaşstırdı̆̆ ifade edilmiştir.
\end{abstract}

Anahtar Kelimeler: Teknoloji ĕgitimi, tutum, motivasyon, ortaokul öğrencileri 


\section{Introduction}

We live in the information era, making technology an important tool in all aspects of education. Technology education should be one of the main components of teaching programs in order to equip individuals with the necessary skills and knowledge for a society. Description and applications of technology education may vary from one country to another. This is often due to cultural differences and the adapting of technology education by different groups according to their needs and resources. In America, for example, technology education starts at pre-school and thus children become familiar with technology at an early age and in Australia, the emphasis has been on the model of "Design, Do and Evaluate" (Black, 1998).

Technology education in European countries and even within a country may show some variations. However, there are some shared aspects between the different aducation systems which understand the world of matters, formulation of design-production-usage concepts and the use of computer as a tool (Dugger, 2001). In Germany, there is a transition from an approach focused on hand-work and industrial production towards an approach emphasising the teaching of technological concepts. In England, the content of industrial arts and technology education is comprehensive, dealing with both theoretical foundations and industrial applications. Technology education is carried out under the headings "Design and Technology" and "Information and Communication" (Correard, 2001). In the Netherlands, technology was declared to be one of the 15 required courses for secondary school children (aged 12-14) in 1993.

In Turkey, prior to 1975, there was no teacher training institution qualified enough to train teachers who could then prepare students for a developing industrial society. Therefore, it was recommended by decrees of the Educational Committee to establish an institution that would serve this purpose. As a result, in 1975 the Industrial Arts Education Faculty was established. Thus, a first attempt was made to provide technology education to young people.

In line with the previously new objectives of acquiring knowledge, experience and scientific values, the Turkish Ministry of National Education (MoNE) ammended the curriculum at the beginning of the 2004-2005 school year and the science course was changed to a science and technology course (MoNE, 2006). It was also recommended that a course called "Technology and Design" be incorporated into the elementary school curriculum.

\subsection{Research in the field of technology education and its importance}

When studies on technology education are reviewed, many reveal the existence of negative attitudes towards technology among students (Osborne, Simon, and Collins, 2003; Volk, Yip and Lo, 2003). However, more recent studies reveal increasingly positive attitudes towards technology (Correard, 2001; Fang et al., 2007; Khunyakari et al., 2009; van Rensburg et al., 1999). Osborne et al. (2003) point out negative attitudes reported by internationally studies carried out in the field of science and technology over the past 20 years. Furthermore, Volk et al. (2003) argued that very few secondary school students were interested in technology. However, a more recent study (Fang et al., 2007) reported that a majority of the public was aware of the importance of being informed about technology. Khunyakari et al. (2009) found that almost all of the middle school students $(n=654 ; 97 \%)$ thought that knowing about technology and using it was important.

When past studies are examined in relation to gender, a trend can be seen among male students seeming to have more positive attitudes towards technology than female students (Becker and Maunsaiyat, 2002; Boser, Palmer and Daugherty, 1998; Francis and Greer, 1999; Khunyakari et al., 2009; van Rensburg et al., 1999; Volk et al., 2003).

\section{Objectives}


Rapid technological changes affect both our societies as a whole and our education systems; requiring both to advance and change as well. Research exploring children's attitudes and adaptation to these changes is essential in developing appropriate pedegogy. Nationally studies in the field of technology understandings and attitudes focused mainly on educational and teaching technologies (Isman, 2002; Kahveci, 2010; Simsek, 2001) and there are few studies dealing with students (Sahin and Ekli, 2013) or science teachers (Ispir, Furkan and Çitil, 2007). The dearth of studies on elementary or middle school students' attitudes towards technology from the Turkish students' perspective are the rationale for the current study. Therefore, the present study investigates the attitudes of $6^{\text {th }}, 7^{\text {th }}$ and $8^{\text {th }}$ grade students towards technology. More specifically, the study seeks to answer the following research questions:

RQ1: What are the students' attitudes towards technology?

RQ2: Do variables such as gender, grade level and social background significantly influence students' attitudes?

RQ3: Are there significant correlations between the students' risk perceptions and their attitudes towards technology?

\section{Method}

The research design and methods are developed within a quantitative research paradigm.

\subsection{Sample}

The study consisted of middle schools students in the urban and rural area. Using the convenience sampling method, the sampling of the study consisted of 1,396 students in the $6^{\text {th }}$ $7^{\text {th }}$ and $8^{\text {th }}$ grades (age range 12-15) attending 23 middle schools. Regarding gender, 708 of the participants were girls (50.7\%) and 688 of them were boys $(49.3 \%)$.

\subsection{Data collection tool}

The Pupils' Attitudes towards Technology (PATT) questionnaire (Bame, Dugger, de Vries and McBee, 1993) is one of the best known students' knowledge of and attitudes toward technology survey instruments. In this study, Turkish version of Pupils' Attitude towards Technology (PATT-TR) scale by Yurdugul and Askar (2008) was used. The factor structures of PATT-USA and PATT-TR show no correspondence, in PATT-TR only four components were identified which are; Tendency to Technology, Negativeness of Technology, Importance of Technology, and Technology for All. Researchers found the PATT- TR scale consisting of 24 items to have a high item-consistency $(\omega=.92)$. It was observed that two sub-constructs "Technology \& Gender" and "Personality Prerequisites" didn't predict the general attitude. Survey instrument was administered under the supervision of the classroom teachers in normal classroom conditions within the 30 minutes or less.

The survey form used in this study consists of 3 sections:

$i$. An open-ended question to solicit a definition of technology from the students

ii. Items to obtain demographic characteristics of the participants (10 item)

iii. Five-point Likert-type items related to the affective domain (24 item)

\subsection{Data analysis}

The data were analyzed with the SPSS 14.00 program package. In the analysis of the data, $t$ tests, arithmetic means $(M)$, standard deviations $(S D)$ and percentages (\%) were employed. The data were comparatively analyzed in relation to various features of the sampling. For the comparison of binary variables, first compliance with the normal distribution tests was carried out. Levene's test was used to determine whether the distributions were normal. For Levene's test, a significance level of 0.05 was determined. In those cases where the distribution was normal, independent-samples $t$ tests and variance 
analysis were used; where the distributions were not normal non-parametric Mann Whitney U and Kruskall-Wallis tests were used.

\section{Results}

\subsection{Technology definitions}

Technology is described in different ways by scientists. Simon (1983) defined it as “... a rational science designed by the man to dominate the nature". Paul Saetller (1967) suggested that "Unlike what many people think, technology does not mean using a machine. Technology is science's turning into an applied branch of art".

Figure 1: Technology definitions

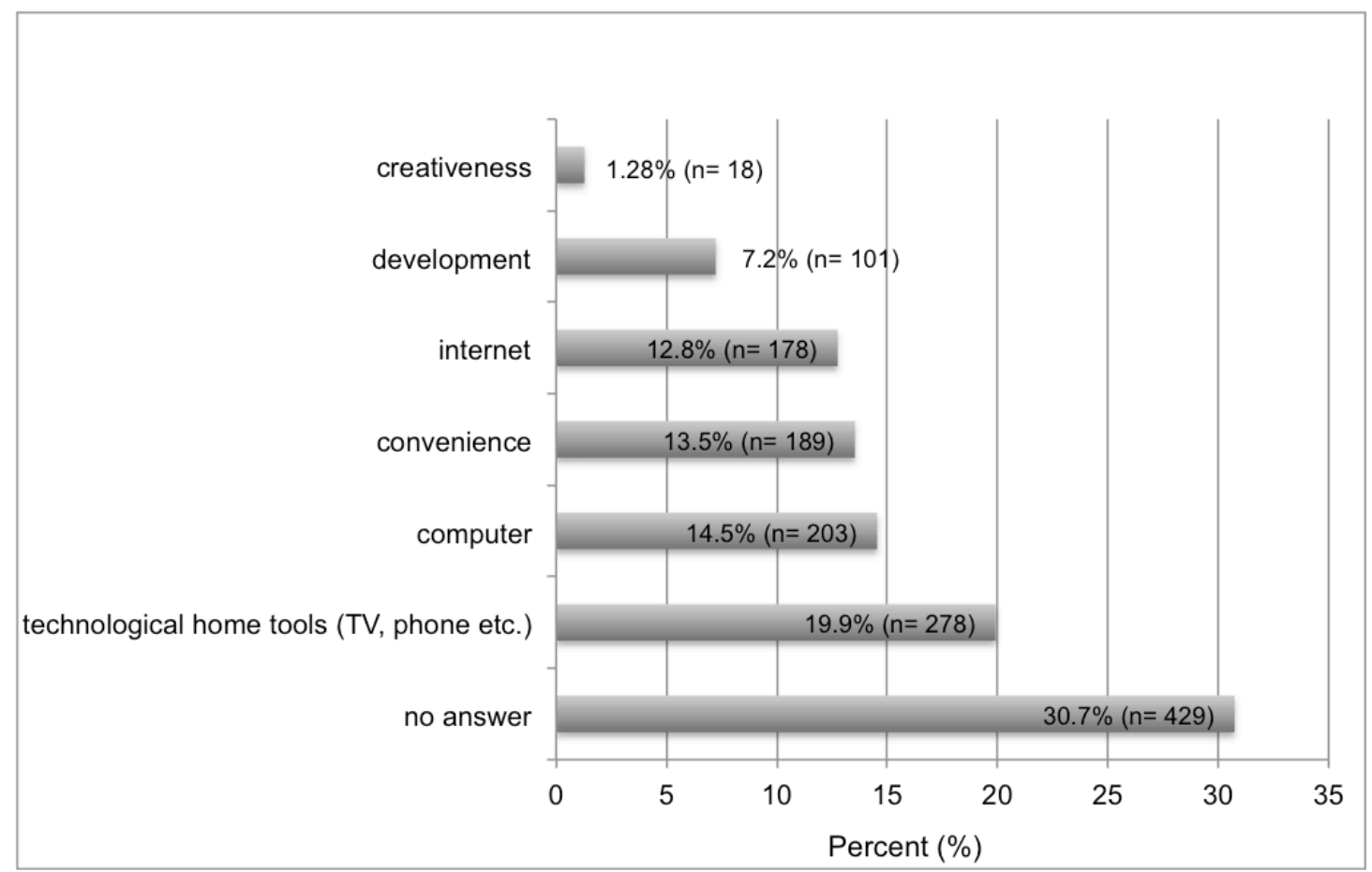

Before administering PATT-TR scale, students were asked through an open ended question what they thought about technology and what they understood by it. A majority of the students did not answer this question. Some of the students (19.9\%) who answered this question stated that when they heard the word technology, they associated it with household appliances such as refrigerators, televisions and telephones. During the interviews, it was found that a large majority of the students stating that they spent a great deal of their spare time in internet cafes thought that technology meant computers and the internet. Some of the female students stated that they used technological devices while doing housework which facilitated their work and, as a result, made it is less tiring. A few students stated that technology meant either development $(n=101,7.2 \%)$ or creativity $(n=18,1.2 \%)$, or that through technology, new devices are invented (Figure I).

\subsection{Tendency towards technology}

Items 1 to 8 in the PATT-TR scale are related to tendency towards technology. When the mean values of the responses to these items were examined, it was observed that the students agreed with the items to a great extent. A large majority of the students stated that 
they either "agree" or "strongly agree" with the tendency items such as "selecting a job related to technology," "having a career in the field of technology," and "preference for a job in the field of technology" $(>40 \%)$. Students' responses showed a positive tendency towards technology.

Some of the students who stated that they most probably would choose a job related to technology $(n=404,28.9 \%)$ also thought that technology should be taught as a course at schools.

\subsection{Discontent towards technology}

Discontent towards technology refers to items such as "technology may harm the welfare of the country," "it may increase unemployment," and "it may result in pollution." When the mean values of the responses given to the items related to discontent with technology (technology may harm the welfare of the country: it may increase unemployment: it may result in pollution), were examined, it was found that most students marked the options "I strongly disagree" $(>30 \%)$ or "I disagree" $(>18 \%)$, demonstrating very little agreement with these items. These results revealed that $48 \%$ of the students had positive attitudes towards technology.

\subsection{Contribution and significance of technology}

This factor group refers to items such as "technology is useful for the future of the country" and "everybody needs technology." When the statistical data obtained for items 1621 concerning the contribution and significance of technology was analyzed, a general result was obtained. The students' responses showed a high level of agreement with the items in this group; (technology is useful for the future of the country: everybody needs technology) and hence they showed a positive attitude towards technology regarding its importance to society.

\subsection{Technology for everybody}

The data obtained from the responses to scale items 22, 23, and 24 are related to the subgroup "Technology is important and necessary for everybody." The data showed that a large majority of the students agreed with the items "technology courses should be given to all students" ( $n=949,68 \%)$; everybody can study technology $(n=730,52.3 \%)$; and everybody can have a job in the field of technology $(n=779,55.8 \%)$.

\subsection{Gender differences}

When the total scores obtained from the responses to the items in the scale were evaluated in relation to gender, there was a significant difference between male and female student responses $\left(M_{(\mathrm{M})}=728.63 ; M_{(\mathrm{F})}=669.23 ; p<.05\right)$.

No significant differences were found in relation to gender for the item groups "Contribution of technology", "Discontent with technology" and "Technology for everyone" $(p>.05)$. However total scores obtained from the item group "Tendency towards technology" showed a significant difference between male and female student responses $\left(M_{(\mathrm{M})}=29.52\right.$; $\left.M_{(\mathrm{F})}=27.75 ; p<.05\right)$. 
Table 1. The statistical values of responses to question items with significant differences in terms of gender organized by factor group.

\begin{tabular}{|c|c|c|c|c|c|c|c|c|}
\hline & $\mathbf{n}$ & $\begin{array}{l}\begin{array}{l}\text { Strongly } \\
\text { disagree }\end{array} \\
\%\end{array}$ & $\begin{array}{l}\text { Disagree } \\
\%\end{array}$ & $\begin{array}{l}\text { Don't } \\
\text { know } \\
\%\end{array}$ & $\begin{array}{l}\text { Agree } \\
\%\end{array}$ & $\begin{array}{l}\begin{array}{l}\text { Strongly } \\
\text { agree }\end{array} \\
\%\end{array}$ & $\mathbf{M}$ & SD \\
\hline \multicolumn{9}{|l|}{ Tendency towards Technology } \\
\hline Q1 & 1396 & 10.3 & 10.1 & 41.3 & 20.6 & 17.7 & $3.25 * *$ & 1.16 \\
\hline Q4 & 1396 & 6.2 & 10 & 23.9 & 32.4 & 27.4 & $3.65 * *$ & 1.16 \\
\hline Q6 & 1396 & 10.2 & 14.5 & 35.8 & 21.3 & 18.3 & $3.23 * *$ & 1.2 \\
\hline Q7 & 1396 & 8.2 & 12.8 & 11.5 & 27.7 & 39.8 & $3.78 * *$ & 1.31 \\
\hline Q8 & 1396 & 5.7 & 8.2 & 27.7 & 31.4 & 26.9 & $3.66^{*}$ & 1.12 \\
\hline \multicolumn{9}{|l|}{$\begin{array}{r}\text { Discontent Towards } \\
\text { Technology }\end{array}$} \\
\hline Q13 & 1396 & 36.7 & 28.3 & 22.1 & 8.5 & 4.4 & $3.84 *$ & 1.14 \\
\hline \multicolumn{9}{|l|}{$\begin{array}{r}\text { Contribution and Significance } \\
\text { of Technology }\end{array}$} \\
\hline Q19 & 1396 & 3.7 & 8.2 & 16.8 & 34.2 & 37.2 & $3.93^{*}$ & 1.09 \\
\hline
\end{tabular}

${ }^{*} p<0.05 ; * * p<0.01$ The relation of question items with gender

To determine which items from this group lead to this difference, the items were evaluated one by one in relation to gender. The following items showed significant differences between male and female students' responses (Table 1):

- Selecting a technology-related job (Q1; $\left.p<.05 ; M_{(\mathrm{M})}=752.23, M_{(\mathrm{F})}=646.29\right)$;

- Preference for a job in the field of technology $\left(\mathrm{Q} 4 ; p>.05, M_{(\mathrm{M})}=3.82, M_{(\mathrm{F})}=3.49\right)$;

- Having a career in the field of technology $\left(\mathrm{Q} 6, p<.05 ; M_{(\mathrm{M})}=754.70, M_{(\mathrm{F})}=643.89\right)$;

- Hoping to have a brilliant future by having a job in the field of technology (Q8; $p>$ $\left..05, M_{(\mathrm{M})}=3.72, M_{(\mathrm{F})}=3.59\right)$.

\subsection{Grade level-based differences}

In order to evaluate the total scores obtained from the responses to the items in the scale in relation to grade level, an ANOVA test was conducted and a significant difference was found $(p<.05, \mathrm{~F}=4.389)$. Dunnett's test indicated that the scores of the $8^{\text {th }}$ grade students were significantly different from the two lower grades.

Item groups which showed the most significant difference in terms of grade level were also investigated. While no significant difference was found for the item group "Discontent with technology" $(p>.05)$, a significant difference favoring the $7^{\text {th }}$ graders $(M=11.05)$ was obtained for the item group "Technology for everybody" $(p<.05)$. Item groups "Tendency towards technology" and "Importance of technology" were analyzed in relation to the grade level variable by means of the Kruskal-Wallis test. While no significant difference was found for item group "Importance and contribution of technology", a significant difference regarding the $7^{\text {th }}$ graders was found for the item group "Tendency towards technology" $(M=$ 756.65).

As a result, it was found that the significant difference regarding $7^{\text {th }}$ graders in relation to the grade level variable stems from the item groups "Tendency towards technology" and "Technology for everybody". 
In order to determine the direction of the difference obtained in relation to the grade level variable, the Duncan and Scheffe tests were conducted and it was found that it stems from the responses of $6^{\text {th }}$ and $7^{\text {th }}$ graders. It was found that the $6^{\text {th }}$ and $7^{\text {th }}$ graders $\left(M_{(6)}=\right.$ $\left.718.48, M_{(7)}=756.65\right)$ had more positive attitudes towards technology than the $8^{\text {th }}$ graders $\left(M_{(8)}=617.28\right)$.

The Duncan and Scheffe tests also revealed that a significant difference obtained for the item group "Technology for everybody" in relation to grade level variable stemmed from the responses of the $8^{\text {th }}$ graders to the item "technology courses should be given to all students". While the agreement ratio of the $6^{\text {th }}$ graders to the item "technology courses should be given to all students" is $25.2 \%$, this ratio is $22.9 \%$ for the $7^{\text {th }}$ graders and $19.9 \%$ for the $8^{\text {th }}$ graders. This observation suggests that with increasing grade level, agreement on technology education for all decreases.

\subsection{Background-related differences}

A majority of the students $(55.2 \%, n=771)$ attended schools located in urban areas and $44.8 \%(n=625)$ of them attended schools in rural areas which are located in socioeconomically more privileged. Students attending schools in urban areas had significantly more positive attitudes towards technology than those attending school in rural areas ( $M_{\text {(urban) }}=$ 89.67, $M_{\text {(rural) }}=88.13, p<.05$ ). This difference in total depends on the item group "Discontent with technology" $(p<.05)$. Students attending urban schools disagreed more with the statements in this group than those attending rural schools. Hence, the urban students had a more positive attitudes towards technology $\left(M_{\text {(urban) }}=26.46, M_{\text {(rural) }}=25.51\right)$.

The relationship between students having parents with technology-related jobs and students' attitudes towards technology was investigated and significant differences were found $(p<.05)$. As the level of correlation between the parents' jobs and technology increased, the attitudes of the students towards technology became more positive.

This study also looked at whether there were significant correlations between students having prior technology training and their attitudes towards technology $(p<.05)$. Those having prior technology training $\left(M^{=} 91.62\right)$ had more positive attitudes towards technology than those without it $\left(M^{=} 88.08\right)$.

Moreover, the study investigated whether having access to items such as computers and Legos had an impact on attitudes towards technology. According to the results of the MannWhitney $U$ test, those having computers showed more positive attitudes $\left(M^{=} 757.91\right)$ than those without computers $\left(M^{=} 632.62, p<.05\right)$, and those having Legos reported more positive attitudes $\left(M^{=} 780.61\right)$ than those without them $\left(M^{=} 634.59, p<.05\right)$.

\section{Discussion and conclusion}

\subsection{Results obtained in relation to demographic features}

\subsubsection{Gender}

Male students had a significantly more positive attitude towards technology than female students. Boser et al. (1998) reported that females had different perceptions of some aspects of technology, and that they mostly viewed technology as an activity and less interesting. In similar studies, it has been reported that male students had more positive attitudes towards technology (Boser, et al., 1998; Deniz et al., 2006; Khunyakari et al., 2009; Ramsden, 1998; Volk and Yip, 1999; Volk et al., 2003).

In this study, it was found that technology was more interesting and attractive for male students, they liked engaging with it in their daily lives and they were more willing to choose a career in this field. On the other hand, while the female students thought that technology 
was important, they were less inclined to take a job and/or make a career in this field. These gender-based differences may stem from disparities in knowledge of technology and the extent to which they make use of it in their daily lives. Boser et al., (1998) concluded that as male students are more willing to increase their knowledge of technology and are more familiar with it than their female counterparts, significant gender-based differences are observed in attitudes towards technology.

\subsubsection{Grade level}

Significant differences were found among the total scores of the students from different grade levels. Sjöber (2002) reported that attitudes towards technology are connected with the perception of its risks and benefits. The more negative attitudes of the $8^{\text {th }}$ graders in this study towards technology may be due to a deeper understanding of its potential risks as information about the potential risks of technology may have negative impacts on its perception.

\subsubsection{Background}

Students attending schools in urban areas showed a significantly more positive attitude towards technology than those attending schools in rural areas. This may be because of the technological opportunities provided by the schools in the urban areas and the socioeconomic status of these students' families. A similar study (Khunyakari et al., 2009) revealed that there is a significant difference between the attitudes of the students attending schools in urban areas and in rural areas. Although a majority of the students attending schools in rural areas thought that information about technology was both necessary and of great importance and necessary, those attending schools in urban areas had more positive attitudes towards technology.

It was also found that the students having parents with technology-related jobs, students having prior technology training, motivation in science and having items such as computers and Legos had a positive impact on the students' attitudes towards technology. Other researchs also showed that technological toys and short-term intensive technologyrelated instruction had a positive impact on students' attitudes towards technology (Becker and Maunsaiyat, 2002; Khunyakari et al., 2009; Volk et al., 2003). However, Boser et al. (1998) found that students' interests and attitudes toward technology were not significantly altered after an instructional program in technology education.

\subsection{Technology definitions}

When asked to define technology, the students in this study mentioned household appliances, computers, and the internet and suggested that technology made life easier. Correard (2001) reported that more than 70\% of 12-14 years old English and French students defined technology as "novelty" and "computer". Likewise, Fang et al. (2007) conducted a study with Taiwanese people (18 years of age or older), and found that they described technology as computers $(42.3 \%)$, science $(19 \%)$, the internet $(11.6 \%)$ and novelty $(9.9 \%)$. These finding show that the students define technology according to their daily interaction with technological tools.

\subsection{Tendency towards technology}

Many of the students showed positive attitudes towards technology. The studies carried out in the past years mostly reported negative attitudes towards and opinions about technology (Osborne et al., 2003; Volk et al., 2003). However, more recent studies (Fang et al., 2007; Khunyakari et al., 2009) have revealed more positive attitudes towards technology. Khunyakari et al. (2009) reported that a majority of Indian middle students stated that it was necessary to be knowledgeable about technology and that this knowledge should be enhanced by using technology. However, some of the students were found to be undecided when choosing a job and career in the field of technology (25\%). Volk and Yip (1999) reported that 
students seemed to be hesitant about having a career in the field of technology but that male students seemed to be more open to the idea of having a career in this field.

\subsection{Discontent with technology}

Some of the students $(40 \%)$ did not show any discontent with technology and they were aware of the benefits and opportunities brought about by developments in this field. Khunyakari et al. (2009) on the other hand, stated that not everyone is aware of the benefits and opportunities brought about by technology. They found that a lack of information about technology along with people's reluctance to acquire this information were the two main factors leading people to distance themselves from technology.

The Science and Technology program that has been gradually implemented in schools in Turkey as of 2006 aims to fill in the gaps of technology-related information for students. These developments seek to aid students in becoming more aware of the opportunities brought about by technology and to encourage more positive attitudes towards it.

\subsection{Importance and contribution of technology}

A large majority of the students thought that technology was both important and necessary. They reported that the benefits of technology were greater than its potential risks; that technology was useful for the country; and that through technology everything functions better. It is generally believed that technological innovations contribute to development, that technology-related information enhances performance, and that use of technology is of great importance for the future and the welfare of society. If this is so, in order to maintain and further progress, technological information should be incorporated in the curricula of schools (Fang et al., 2007; Khunyakari et al., 2009; van Rensburg et al., 1999).

\subsection{Technology for everybody}

The students' responses to the items in this group indicated that they believe everybody can do something with technology. Volk et al. (2003) found that very few people were interested in technology and the level of technology-related information was very low. Use of technology and technology-related information should be known by everyone, particularly teachers (Becker and Maunsaiyat, 2002; Khunyakari et al., 2009; Rohaan, Taconis, and Jochems, 2010, van Rensburg et al., 1999; Volk et al., 2003).

\section{Recommendations and implications}

Lack of information in the field of technology leads to the development of negative attitudes towards technology. In order to help students develop positive attitudes, they should be informed about all aspects of technology. Practical applications should be provided for female students to make them more comfortable performing technological tasks, and to stimulate curiosity about the uses of technology. Innovative technology programmes in secondary schools were found to have much more effective on students' attitudes than traditional ones (Volk et al. 2003).

While students are attending elementary school, it may not be enough to inform by teachers about technology (Rohaan et al., 2010), they should learn how to integrate the technology into their curricula (Mundy, Kupczynski, and Kee, 2012). Families also play an important role in student education. Therefore, they should also be informed about technology and its developments. It was found that devices and toys such as computers and Legos contribute to the development of positive attitudes towards technology. Hence, schools should be equipped with such items and students should have easy access to them. By consolidating students' interests in emerging technologies such as bio-technology and nanotechnology, students may become more well-informed and may develop more positive attitudes towards technology. 
This study demonstrated middle school students' perceptions of technology. However, the results were limited by the sample of participants $(N=1,396)$. A repeat survey of this study in a more diverse settings and samples may more informative to understand how middle school students think about technology.

\section{Competing interests}

All authors declare that they have no competing interests.

\section{Authors' contributions}

NS designed the project and drafted most of the manuscript. EE carried out the survey. SD performed quantitative analysis. All authors contributed to the writing of the overall discussion and evaluation, edited the manuscript, and read and approved the final manuscript.

\section{References}

Bame, E., Dugger, W., Jr., de Vries, M., \& McBee, J. (1993). Pupils' attitudes toward technology - PATT-USA. J. Tech. Stud 19(1), 40-48.

Becker, K.H., \& Maunsaiyat, S. (2002). Thai students' attitudes and concepts of technology. J. Tech. Educ 13(2), 6-20.

Boser, R., Palmer, J. D., \& Daugherty, M. K. (1998). Students attitudes toward technology in selected technology programs. J. Tech. Educ 10(1), 4-19.

Black, P. (1998). An international overview of curricular approaches and models in technology education. J. Tech. Stud 24(1), 24-30.

Correard, I. (2001). Twelve years of technology education in France, England and the Netherlands: How do pupils' perceive the subject, pp.51-58. In Proceedings PATT-11 Conference: New Media in Technology Education. Haarlem, Netherlands. Retrieved from http://www.iteaconnect.org/Conference/PATT11/Correarddef.pdf

Deniz, S., Gorgen, I., \& Seker, H. (2006). Attitudes of prospective teachers attending master program without thesis towards technology. Eurasian J. Educ. Res 23, 62-71.

Dugger, W. E. (2001). New Media and Standards for Technological Literacy. In: Proceedings PATT-11 Conference: New Media in Technology Education, 8-13 March 2001, Haarlem, Netherlands, pp. 66-74.

Fang, R., Teng, C., \& Chen, C. (2007). How Taiwanese and Americans think about technology. J. Tech. Educ 18(2), 7-23. Retrieved from http://scholar.lib.vt.edu/ejournals/JTE/v18n2/fang.html

Francis, L.J., \& Greer, J. E. (1999). Measuring attitude towards Science among secondary school students: the affective domain. Res. Sci. Technol. Educ 17(2), 219-226.

Isman, A. (2002). Educational technology proficiencies of teachers in the Sakarya province. [in Turkish] Turk. Online J. Educ. Tech 1(1), 72-91. Retrieved from http://eefdergi.erzincan.edu.tr/article/view/1006000698

Ispir, E., Furkan, H., \& Çitil, M. (2007). College science teachers' attitudes towards technology-Kahramanmaraş sample. [in Turkish] J. Erzincan Educ. Facul 9(1), 63-72.

Kahveci, M. (2010). Students' perceptions to use technology for learning: Measurement integrity of the modified Fennema-Sherman attitudes scales. Turk. Online J. Educ. Tech 9, 185-201. Retrieved from http://files.eric.ed.gov/fulltext/EJ875782.pdf

Khunyakari, R., Mehrotra, S., Natarajan, C., \& Chunawala, S. (2009). Studying Indian Middle School Students' Attitudes towards Technology. In: Proceedings of the International Conference to Review Research in Science, Technology and Mathematics EducationepiSTEME-3, 5-9 Jan 2009, Mumbai, India, pp.81-88. Retrieved from http://cvs.gnowledge.org/episteme3/pro_pdfs/13-ritesh-sm-cn-sc.pdf

MoNE (2006). Primary school technology and design teaching curriculum and manual $6^{\text {th }}, 7^{\text {th }}$, and $8^{\text {th }}$ grades. [in Turkish] Republic of Turkey Ministry of National Education (MoNE), Tebligler Dergisi, 69, 577. 
Mundy, M. A., Kupczynski, L., \& Kee, R. (2012). Teacher's Perceptions of Technology Use in the Schools. SAGE Open 2(1). doi:10.1177/2158244012440813

Osborne, J., Simon, S., \& Collins, S. (2003). Attitudes towards science: A review of the literature and its implications. Int $J$ Sci Educ 25(9), 1049-1079. doi: 10.1080/0950069032000032199.

Ramsden, J. M. (1998). Mission impossible?: Can anything be done about attitudes to science Int J Sci Educ 20(2), 125-137. doi:10.1080/0950069980200201.

Rohaan, E., Taconis, R., \& Jochems, W. G. (2010). Reviewing the relations between teachers' knowledge and pupils' attitude in the field of primary technology education. Int $J$ Technol Des Educ 20(1), 15-26. doi:10.1007/s10798-008-9055-7

Saettler, L. P. (1967). A history of instructional technology; McGraw-Hill: New York, USA. Sahin, N., \& Ekli, E. (2013). Nanotechnology awareness, opinions and risk perceptions among middle school students. Int J Technol Des Educ, 23(4), 867-881. doi:10.1007/s10798013-9233-0

Simon, Y. R. (1983). Pursuit of happiness and lust for power in technological society. In Philosophy and Technology; Mitcham, C., Mackey, R. (Eds.), p.173. New York, NY: Free Press.

Simsek, N. (2001). International aspect of trends in educational technology. Ankara Univ $J$ Educ Sci Facul 34(1), 77-87.

Sjöber, L. (2002). Attitudes toward Technology and Risk: Going Beyond What is Immediately Given. Policy Sci 35(4), 379-400.

van Rensburg, S., Ankiewicz, P., \& Myburgh, C. (1999). Assessing south Africa learners' attitudes towards technology by using the PATT (Pupils' Attitudes Towards Technology) Questionnaire. Int J Technol Des Educ 9(2), 137-151. doi:10.1023/A:1008848031430

Volk, K., Yip, M.W., \& Lo, T. K. (2003). Hong Kong pupils' attitudes toward technology: The impact of design and technology programs. J Tech Educ 15(1), 48-63. (online) Retrieved from http://scholar.lib.vt.edu/ejournals/JTE/v15n1/pdf/volk.pdf

Volk, K.S., Yip, \& M.W. (1999). Gender and technology in Hong Kong: A study of pupils' attitudes toward technology. Int J Technol Des Educ, 9(1), 57-71.

Yurdugul, H., \& Askar, P. (2008). An investigation of the factorial structures of pupils' attitude towards technology (PATT): Elementary Educ Online, 7(2), 288-309. Retrieved from http://ilkogretim-online.org.tr/vol7say2/v7s2m5.pdf

\begin{tabular}{|l|l|}
\hline Nurettin SAHIN & $\begin{array}{l}\text { Prof. Dr. Muğla Sitkı Koçman Üniversitesi Eğitim Fakültesi, Menteşe, } \\
\text { Muğla. E-mail: nsahin@mu.edu.tr }\end{array}$ \\
\hline Emel EKLI & Öğretmen, M.E.B. Güney Ortaokulu, Yeşilova-Burdur \\
\hline Sabahattin DENIZ & $\begin{array}{l}\text { Doç. Dr. Muğla Sitkı Koçman Üniversitesi Ĕ̆itim Fakültesi, Menteşe, } \\
\text { Muğla. E-mail: sdeniz@mu.edu.tr }\end{array}$ \\
\hline
\end{tabular}

